\title{
Vanquishing temporal distance: Malraux, Art and Metamorphosis.
}

\author{
Derek Allan, Australian National University
}

On first encounter, the topic "proximité/distance" tends to make us think of geography and spatial distance. The distance to be discussed in the present article is, however, of a different kind: distance in time. The subject here is the gulf, sometimes very large, that separates us from the past and the astonishing, not to say miraculous, power possessed by works of art to bridge that gulf - to replace distance by proximity.

The writer I will call in aid to address this issue is the twentieth-century novelist and art theorist, André Malraux. Malraux is a name well known to students of French literature, and given that he wrote extensively on the theory of art, one would expect him to be well known to contemporary philosophers of art as well. Sadly, this is not the case. In Englishspeaking countries especially, Malraux's writings on art are almost always absent from the agendas of conferences and courses of study concerned with the philosophy of art (or aesthetics, as the discipline is also called), and leaving aside sporadic references to his concept of the musée imaginaire, his theory of art is seldom mentioned. ${ }^{2}$

This situation is unfortunate because Malraux's thinking, which is explained in detail in works such as Les Voix du silence and La Métamorphose des dieux, makes a major contribution to our understanding of the nature and significance of art. Malraux is one of the rare modern thinkers who offers a persuasive alternative to the traditional accounts of art based on notions of beauty, aesthetic pleasure and taste, which we have inherited from Enlightenment thinkers such as Hume and Kant. In doing so, he not only provides solutions to a number of serious dilemmas confronting modern aesthetics (such as the doubtful importance of beauty in many of the objects we now regard as works of art) but also, and just as importantly, furnishes credible explanations for a number of major issues that modern aesthetics has almost completely overlooked.

\footnotetext{
${ }^{1}$ This was part of theme of the conference for which this paper was originally written.

${ }^{2}$ One exception is the art historian E. H. Gombrich who commented on Malraux's Les Voix du silence and La Métamorphose des dieux not long after their publication in English translation. Unfortunately, as I have argued in some detail elsewhere, Gombrich's accounts are open to serious question. See Derek Allan, "'Reckless Inaccuracies Abounding': André Malraux and the Birth of a Myth", The Journal of Aesthetics and Art Criticism, 67, no. 2 (2009), 147-158; and Derek Allan, Art and the Human Adventure: André Malraux's Theory of Art (Amsterdam: Rodopi, 2009).
} 
One such issue, which is directly relevant to the topic of the present paper, is the relationship between art and time - or in the terms used above, the gulf separating us from the past and the power of art to bridge that gulf. Oddly enough, modern aesthetics has had almost nothing to say about this topic. Now and then, the discipline turns its attention to issues concerning the significance of time within works of art, such as the different ways one might represent the passing of time in film or the novel. But those are matters of a quite different stamp. The issue at stake here relates to the work of art's external relationship with time and its capacity to vanquish the distances of centuries or millennia that separate it from the present - or, in the customary terminology, the work's capacity to defy or transcend time. In André Malraux apt words the issue here is the capacity of certain human creations to become "la présence, dans notre vie, de ce qui devrait appartenir à la mort". ${ }^{3}$

Given the widespread neglect of this topic in contemporary philosophical discourse, the following discussion will begin from first principles and proceed step by step. Most people are doubtless familiar with the somewhat banal observation that great works of art endure - or "live on" - while lesser works do not. We know, for instance, that of the thousands of novels published in the eighteenth century, only a tiny fraction holds our interest today, and that for every Les Liaisons dangereuses or Tom Jones, there are large numbers of works by contemporaries of Laclos and Fielding that have sunk into oblivion, probably permanently. And if we draw comparisons with objects outside the realm of art, the point is equally obvious. We are unlikely to believe, for example, that a map of the world drawn by a cartographer of the seventeenth century could still function as a reliable navigational tool, and we know that a ship's captain today who relied on such a map would be acting very unwisely. But we might quite sensibly ask if Racine's tragedies, written at the same time the map was drawn, are still pertinent to life today, and we might well want to answer yes. The map has survived as an object of what we term "historical interest" but is no longer applicable to the world we live in. Racine's plays, by contrast, are not just part of history (even though one might also view them in that light); they have endured in a way the map has not.

Now, this idea is so familiar that we mostly just take it for granted. Indeed, to say that great works of art endure, or "live on", borders on cliché. But once we pause to reflect on it, we begin to see that this cliché is, after all, rather perplexing and even, perhaps, quite

\footnotetext{
${ }^{3}$ André Malraux, La Métamorphose des dieux: Le Surnaturel, Ecrits sur l'art (II), ed. Henri Godard (Paris: Gallimard, 2004), p. 33.
} 
astonishing. What are we really saying? We are claiming that certain human creations have a power to defeat time, and that unlike other products of human invention, they are somehow resistant to the relentless effects of time and change - not, of course, in the physical sense (indeed, works of art are often more fragile than other objects) - but in the sense that they transcend the moment of their creation and remain vital and alive long afterwards. Cliché it may be, but it is nonetheless an intriguing one. How is it possible that in a world in which everything - from maps, to social customs, to beliefs about the gods - eventually becomes outmoded, obsolete, and at best of only "historical interest", a small number of exceptions is able to defy this rule and, to use the conventional phrase again, "live on"?

It may seem strange that such an intriguing feature of art receives so little attention in modern aesthetics, but it becomes even more so once we remember that the very same question, and a certain familiar answer to it, was once a major theme in European thought, and remained so for some five hundred years. For it was precisely in answer to this question that European artists and thinkers, from the Renaissance onwards, came to the conclusion that art possesses a unique power that allows it to be exempt from time and impervious to change - that it is "immortal", "eternal" or "timeless".

This conclusion had not, of course, emerged out of the blue without reason; it was a response to a pressing question. The Renaissance had experienced the astonishing resurrection of the art of antiquity; but that had raised an obvious question: How was it possible that the pagan works of ancient Greece and Rome, which had been ignored or scorned for a thousand years, now seemed radiant with life as if they had somehow leapt across the intervening centuries and escaped the passage of time? What power could make such a thing possible? The answer that was given was both simple and daring, and left a lasting impression on subsequent European thinking about the nature of art: The works of antiquity, like those that Renaissance artists were themselves creating, possessed a demiurgic power called "beauty", and beauty, like the goddess Venus who was its supreme representative, is eternal, unaffected by the passing of time, "time-less", immortal. In the terminology of the topic distance/proximité, the question of distance - temporal distance in this case - does not arise because art inhabits a privileged region in which considerations of that kind do not apply.

It is important to recognise the full significance of this proposition. "Eternal", "timeless", and equivalents such as "immortal" do not simply mean "lasts a long time". They 
mean exempt from time - liberated from time. In principle, something might endure in a number of ways. It might endure for a given period and then disappear definitively into oblivion. It might endure for a time, disappear, and then return with its original significance, in a cyclical way. It might endure just as it is without change, timelessly - the alternative under consideration at present. And, as we shall see later, there is at least one other important possibility. So the answer the Renaissance gave was a complete answer: it did not simply assert that art had a special power to endure; it defined that power. Art, it said, is proof against time; it is timeless.

The philosophical study of art and beauty - aesthetics - did not emerge until the eighteenth century but such was the impact on Renaissance minds of the belief that art is timeless that it quickly found expression in other ways, above all in poetry. The well-wrought poem became a warrant of eternal life for the person it praised, a theme one encounters again and again in writers such as Petrarch, Ronsard, Drayton, Spenser and Shakespeare. "What trophy then shall I most fit devise," asks Spenser, "In which I may record the memory/Of my love's conquest [...]? Even this verse, vowed to eternity,/Shall be thereof immortal monument." And examples in Shakespeare, almost too well known to require quotation, include the familiar lines of Sonnet 18:

But thy eternal summer shall not fade

Nor lose possession of that fair thou ow'st;

Nor shall Death brag thou wander'st in his shade,

When in eternal lines to time thou grow'st:

So long as men can breathe or eyes can see,

So long lives this and this gives life to thee.

The belief enshrined in works such as these became a central pillar of European thinking about art. When, a century and a half after Shakespeare, the philosophical discipline of aesthetics began to take form, the notion of beauty was at its core and thinkers simply took it for granted that the finest works of art, ancient or modern, foregathered in an eternal realm impervious to time and circumstance. David Hume, for instance, writes that the function of a suitably prepared sense of taste is to discern that "catholic and universal beauty" found in all true works of art, and that the forms of beauty thus detected will "while the world endures [...] maintain their authority over the mind of man", a proposition he supports by his oftquoted dictum that "The same Homer who pleased at Athens and Rome two thousand years

\footnotetext{
${ }^{4}$ From the sonnet beginning "The famous warriors of the anticke world".
} 
ago, is still admired at Paris and London." "And as late as 1857, in an explicit reaffirmation of the timelessness of art, Théophile Gautier wrote in the poem L'Art:

\section{Tout passe. L'art robuste \\ Seul a l'éternité; \\ Le buste \\ Survit à la cité.}

One might perhaps be tempted to assume that in our modern world, with its pragmatic, down-to-earth values, the idea that art is exempt from time would struggle to find advocates. But this does not seem to be entirely true. Reviewers in newspapers and magazines still speak of a novel's "timeless prose", a melody that has "immortalized" its composer, and so on. And despite modern aesthetics' neglect of the relationship between art and time, one contemporary philosopher of art is happy to claim that "There is a tendency among scholars and non-scholars alike to think that art works, or more specifically, great art works, are in some sense immortal", adding that he himself sees "some truth in the view". ${ }^{6}$ In a similar vein, the contemporary French philosopher Jean-Luc Nancy argues that the beauty of art is eternal (a word which, as he points out, "ne veut pas dire ce qui dure longtemps mais ce qui est hors du temps"). ${ }^{7}$ And a contributor to a 2009 issue of the British Journal of Aesthetics claims that "Classics are timeless and transcendental, appealing to all historical eras, because they capture what is essential about humanity", ${ }^{8}$ the suggestion apparently being that great art is timeless because it expresses timeless truths.

Thus, the notion that art is timeless continues to claim its adherents, even if support seems to have become rather patchy. The question before us now, however, is whether this time-honoured explanation of the temporal nature of art is still plausible - whether it continues to provide a persuasive explanation of the capacity of art to endure - and, if not, what explanation might replace it. The claim to be made here is quite unequivocal. It will be argued in what follows that the belief that art endures timelessly is no longer credible and that

\footnotetext{
${ }^{5}$ David Hume, Of the Standard of Taste, and other essays, ed. J.W. Lenz (Indianapolis: BobbsMerrill, 1965), p. 9.

${ }^{6}$ Christopher Perricone, “Art and the Metamorphosis of Art into History”, British Journal of Aesthetics, 31, no. 4 (1991), 310-321. p. 310.

${ }^{7}$ Jean-Luc Nancy, La Beauté, Les petites conférences (Montrouge: Bayard, 2009), 39.

${ }^{8}$ A. Hamilton, "Scruton's Philosophy of Culture: Elitism, Populism, and Classic Art", British Journal of Aesthetics, 4, no. 49 (2009), 389-404. p. 403.
} 
unless one simply opts to ignore the problem of how art endures (as modern aesthetics has largely chosen to do) there is an urgent need for a new explanation that does not suffer from the weaknesses now plainly visible in this long-standing belief.

The weaknesses are of two kinds. First, the notion that art is exempt from time has been under serious attack since the nineteenth century when writers such as Hegel, Marx and Taine began to situate art, along with all other human activities, within the flow of history. In his influential Philosophie de l'Art published in 1873, Hyppolite Taine writes, for example, that:

Pour comprendre une œuvre d'art, un artiste, un groupe d'artistes, il faut se représenter avec exactitude l'état général de l'esprit et des mœurs du temps auquel ils appartenaient. Là se trouve l'explication dernière ; la réside la cause qui détermine le reste. $^{9}$

Elaborated in different ways by different theorists, the basic thought underlying this comment continues to be influential today - especially in the so-called "Continental" branch of aesthetics which looks to writers such as Theodor Adorno, Jean-Paul Sartre and Walter Benjamin who, like Hegel, Marx and Taine, also frown on any attempt to isolate art from history. ${ }^{10}$ The effect of such arguments on the proposition that art is timeless is not difficult to see. If something is understood as timeless, it is exempt from change - above the battle of history, so to speak. But finesse the matter how we will, we cannot argue that something is, at one and the same time, exempt from change yet essentially a creature of its historical context - simultaneously outside time and within it. Thus, the proposition that art belongs within the flow of history attacks the concept of timelessness like a powerful corrosive. Prior to the nineteenth century there was no serious challenge to this concept - which is doubtless why the Enlightenment founders of the discipline of aesthetics seem to have had so few qualms about ratifying the Renaissance view. But for a century and a half at least, this has no longer been the case. Certainly, the notion that art is part of history offers no explanation of why art endures, but it does present a direct challenge to the claim that art is exempt from time. In

\footnotetext{
${ }^{9}$ Hippolyte Taine, Philosophie de l'Art, vol. 1 (Paris: Hachette, 1948), p. 7.

${ }^{10}$ Contemporary philosophical aesthetics divides roughly into two schools: Anglo-American (or "analytic") and Continental. While the distinction is not clear-cut, Continental thinkers tend to be more strongly influenced by the concerns with historical change that originated with figures such as Hegel and Marx. (The labels do not necessarily denote geographical location: there are many "Continental" thinkers in English-speaking countries and substantial numbers of "analytic" thinkers in Europe.)
} 
effect, there is now an intellectual stalemate between two irreconcilable ideas - a state of affairs that has gravely weakened the traditional belief that art is exempt from time.

The second weakness in this belief is even more serious, and quickly becomes apparent once we reflect on the far-reaching changes that have taken place in our world of art over the past century or so. If an art connoisseur in the mid-nineteenth century had been asked which works he or she regarded as worthy of the name "art", the answer would have focused exclusively on European post-Renaissance art from about Raphael onwards, plus selected works from ancient Greece and Rome. The answer would not have included anything from pre-Renaissance Europe, such as the Gothic, Romanesque and Byzantine periods, or from non-European cultures, such as India, Africa, ancient Egypt or PreColumbian America. Sculptures, figurines, paintings and so on created in cultures such as these were not regarded as "bad art"; they were simply not art at all, and had nothing in common with the works of, say, Raphael, Titian, Watteau, or David. Artefacts from cultures such as Hindu or Buddhist India, tribal Africa, ancient Egypt, and Pre-Columbian America were certainly not unknown: examples had often been brought back to Europe and placed in cabinets de curiosités; and Gothic, Romanesque and Byzantine works were, of course, in plain sight on cathedrals and basilicas across the length and breadth of Europe. But there was no question of regarding any of these objects as art. At best, they were clumsy, botched attempts to do what Raphael and his successors had done; nothing more. ${ }^{11}$

But how vastly and dramatically our world of art has changed since then! Since the close of the nineteenth century, the range of objects welcomed into art museums has embraced a steadily increasing number of works from non-European cultures, past and more recent, as well as from the once-despised Gothic, Romanesque and Byzantine periods. It is as if the eyes with which we today look at the works of other cultures are no longer the same as the eyes of our forebears. The very meaning of the term "art" has changed, giving birth to what Malraux aptly terms "the first universal world of art" - a world which, for the first time, encompasses works from cultures from the four corners of the earth, past and present.

Once we take this unprecedented development into account, however, we quickly see a fatal weakness in the traditional notion that art is timeless. Consider just two examples of new entrants (so to speak) into our modern universal world of art: an ancient Egyptian

\footnotetext{
${ }^{11}$ For Malraux's excellent discussion of this issue, see La Métamorphose des dieux: Le Surnaturel, Ecrits sur l'art (II), p. 8 et seq.
} 
sculpture such as the celebrated image of the Pharaoh Djoser dating from around $2600 \mathrm{BC}$, and any of the superb statues of Old Testament figures on the Royal Portal of Notre-Dame de Chartres, sculpted about 1150 . These works were created for religious purposes in cultures in which the notion of "art" in anything resembling its modern sense was quite unknown. The statue of the Pharaoh Djoser, originally placed in a mortuary temple beside his pyramid, was a spiritual "double" to which offerings were brought to aid the God-King in the Afterlife. The statues on the Royal Portal at Chartres, like all medieval sculpture, had one purpose only - to evoke God's sacred, eternal world and to serve as an aid to worship. The idea that either statue might be something called a "work of art" and that its purpose was simply to be admired and - even worse - admired alongside gods and spirits from other cultures (as in an art museum today) would never have crossed the minds of those who created it, or those for whom it was created. That would have been an unthinkable thought - as appropriate as a visitor to an exhibition of Picasso's paintings today thinking he should fall to his knees and worship them.

Yet the simple fact is that the statue of Djoser and the sculptures on the Royal Portal are now very much part of our modern universal world of art - our musée imaginaire as André Malraux would say - alongside large numbers of other works which, like these, were created in cultures in which the notion of art was non-existent. All such works, many of which are now considered masterpieces, have become something they never were - and were once something that, in modern Western culture at least, they no longer are. There has been a transformation in significance, a process that Malraux quite correctly terms a metamorphosis. In many cases (and Djoser and the Chartres statues are good examples) the emergence as works of art was preceded by long periods in oblivion - long centuries in which they were regarded with indifference or disdain - and in these cases the metamorphosis was accompanied by what Malraux aptly calls a resuscitation or a resurrection. But whether or not this is so, large numbers of works in our modern universal world of art are there by virtue of a metamorphosis that has transformed them into something there were not - into what we now call works of art.

How plausible does the idea of timelessness seem when viewed against this background? If something is timeless, it is exempt from change - proof against the vicissitudes of time and circumstance. Yet our modern universal world of art includes large numbers of works, like the two examples just considered, which are only part of that world 
because they have undergone change - for instance, from sacred object when originally created, then to worthless idol, and now to treasured work of art. Far from being exempt from change, they have endured by means of change. Time and circumstance have played a crucial role, not only in terms of whether or not they were considered important but also in terms of the kind of importance placed on them. Discussing the same point in a television interview in 1975, Malraux commented with characteristic forcefulness that although the notion that art is timeless may have seemed reasonable enough in the past, ${ }^{12}$ it is no longer believable. "L'idée d'une beauté immortelle pour nous est tout simplement saugrenue", he said. "Venir parler aujourd'hui, devant l'histoire de l'art, d'un art immortel, c'est strictement parler pour rien dire." 13

The significance of Malraux's argument has rarely been appreciated. He is saying, quite unequivocally, that the belief on which the West has relied for so long to explain the capacity of art to transcend time must now be discarded - that it is defunct, misleading, useless. He is saying that the proposition to which the Renaissance was so profoundly attached, that the Enlightenment founders of aesthetics regarded as a given (and which influenced so much of their thinking about art), and in which the Romantics placed so much faith, is now, as he puts it, mere empty words. This is no small claim: it is not some fine point about a marginal aspect of art. It is a claim that goes to the heart of the way Western culture has thought about art for half a millennium. In intellectual and cultural terms, it is a deeply revolutionary idea.

Malraux explores his argument in considerable depth in Les Voix du silence and La Métamorphose des dieux, and in doing so sets it on a solid theoretical foundation - that is, on a foundation that does not depend solely on historical evidence of the kind just discussed but also anchors it in his fundamental claims about the nature and significance of art. In the present context, it is not possible to give a detailed account of this aspect of his thinking $-\mathrm{a}$ task I have undertaken elsewhere ${ }^{14}$ - but certain key points should, nevertheless, be briefly explained.

\footnotetext{
${ }^{12}$ That is, until the close of the nineteenth century, prior to which, as discussed, the rubric "art" was much more limited in scope.

${ }^{13}$ André Malraux, Promenades imaginaires dans Florence. (Television series: Journal de Voyage avec André Malraux.) (Paris: Interviewer: Jean-Marie Drot 1975).

${ }^{14}$ See Derek Allan, Art and the Human Adventure: André Malraux's Theory of Art (Amsterdam: Rodopi, 2009), esp. Chapters Three and Six. I also discuss this question in some depth in Derek Allan, Art and Time (Newcastle upon Tyne: Cambridge Scholars Publishing, 2013).
} 
Malraux's theory of art departs radically from the tradition of post-Enlightenment aesthetics with its familiar triad of ideas: beauty, aesthetic pleasure and taste. ${ }^{15}$ For Malraux, an understanding of the fundamental nature of art begins with a metaphysical insight "metaphysical" in the Pascalian sense in which it refers to questions about the ultimate meaning of life and, specifically, in Malraux's case, to humanity's sense of subjection to an unknown scheme of things in which human wishes seem to count for nothing. Art, Malraux argues, is one of the ways humanity resists the sense of impermanence, chaos and futility implicit in this human condition. It responds to the same sense of the inapprehensible and the absurd to which religious faiths respond (albeit, as we shall see, in a different way). Art, he writes in a well-known comment, is a means man has discovered "pour nier [son] néant". ${ }^{16}$

How does this occur? Art combats humanity's fundamental sense of ephemerality and insignificance, Malraux replies, by creating another world, a rival world - not necessarily a supernatural or glorified one, he writes, but "un monde irréductible à celui du réel". ${ }^{17}$ Irreducible in what sense? Irreducible because the rival worlds of art replace chaos with unity: they replace the fundamental anarchy of the world tout court, in which nothing seems to have any reason for being the way it is, with a world constructed solely of elements that are the way they are for a reason. All artistic styles, he writes in a key passage,

sont $[\ldots]$ des significations [...] nous les avons toujours vus substituer, au système inconnu du monde, la cohérence imposée par eux à ce qu'ils "représentent". Aussi complexe, aussi déchiré que se veuille un art - même celui de Van Gogh ou de Rimbaud - au regard du chaos et de la vie il est unité. ${ }^{18}$

How does this relate to the capacity of art to endure and, specifically, to the claim that it endures through a process of metamorphosis? The answer is quite straightforward. Art creates a rival, coherent world. But unlike a religion or a secular absolute, it makes no claim

\footnotetext{
${ }^{15}$ Some writers might demur. Jean-Pierre Zarader, for example, argues that major aspects of Malraux's theory of art can be related to the thinking of figures such as Kant, Hegel, Walter Benjamin, Nancy and Derrida. See for example, Jean-Pierre Zarader, André Malraux: Les Ecrits sur l'art (Paris: Les Editions du cerf, 2013), and Jean-Pierre Zarader, Malraux ou la pensée de l'art: une approche philosophique (Paris: Ellipses, 1998).

${ }^{16}$ André Malraux, Les Noyers de l'Altenburg, Euvres Complètes (II), ed. Marius-François Guyard, Maurice Larès, and François Trécourt (Paris: Gallimard, 1996), 665.

${ }^{17}$ André Malraux, Les Voix du silence, Ecrits sur l'art (I), ed. Jean-Yves Tadié, 2 vols. (Paris: Gallimard, 2004), pp. 538-539. Malraux's emphasis.

${ }^{18}$ Les Voix du silence, Ecrits sur l'art (I), p. 544.
} 
about the underlying nature of things - the eternal Truth beneath the veil of appearances. In this sense all art, one might say, is agnostic. Unlike an absolute, which pronounces that all things are the way they are for a reason (such as the will of God), art speaks only of its own rival world, leaving "the nature of things" - underlying Truth - unknown and unknowable. Art in other words makes the world one, but does not assert that there is only one world - a world created "once and for all". Thus, while the worlds created by art are coherent, they are never fixed - never final. They are worlds born to metamorphosis - worlds to which metamorphosis is intrinsic. To borrow Malraux's formulation of the point, "La métamorphose est [...] la vie même de l'œuvre d'art dans le temps, l'un de ses caractères spécifiques." ${ }^{19}$ Far from being impervious to change, art lives and has its being in a world of change, with all the unpredictability and vulnerability to circumstance that implies.

This argument, which provides the theoretical underpinning for the concept of metamorphosis, immediately allows us to make sense of the puzzling discontinuities and transformations highlighted in earlier comments about the relationship between art and time. A work might, for example, begin its life as a sacred object within a particular religious context - a Pharaoh's "double", for instance, placed in his mortuary temple to receive the offerings of his subjects. Subsequently, when the beliefs with which that significance was associated have disappeared, it might recede into obscurity as did the works of ancient Egypt for some fifteen hundred years, or as Byzantine art did after Giotto, or as Giotto himself did for three centuries after Leonardo and Raphael. In such cases, it is as if the work inhabits, for a time, a kind of limbo in which it evokes at best indifference, at worst contempt. It returns to life and regains human importance only if and when, with the passing of time and its own capacity for metamorphosis, it is able to re-emerge - once again as a coherent world acting as a defence against the chaos of appearances, but with a significance quite different from that which it originally held. Thus the works of ancient Egypt, Byzantium, and Giotto ceased to be sacred images created for tomb, basilica or chapel, and became, after lengthy periods of obscurity, "works of art" in the sense that phrase has for us today. This does not, of course, explain why those particular changes took place when they did. (Malraux has much to say about this subject which there is no space to examine here.) It does, however, explain the nature of the process in question - the capacity of the work of art, in the fundamental sense of coherent but not fixed world, to acquire different significances, including none at all, at

${ }^{19}$ André Malraux, La Métamorphose des dieux: L'Intemporel, Ecrits sur l'art (II), ed. Henri Godard (Paris: Gallimard, 2004), p. 971. 
different periods of time and to do so not simply as a chance consequence of events (for metamorphosis, as Malraux writes "n'est pas un accident". ${ }^{20}$ ) but by virtue of its own nature its capacity for metamorphosis. Thus, the destiny of any great work, Malraux argues, is inseparable from a dialogue - though at times a dialogue of the deaf - between the changing human present and the work's own, continually changing significance. We recognise, he writes,

que si la mort ne contraint pas le génie au silence, ce n'est pas parce qu'il prévaut contre elle en perpétuant son langage initial, mais en imposant un langage sans cesse modifié, parfois oublié, comme un écho qui répondrait aux siècles avec leurs voix successives: le chef-d'œuvre ne maintient pas un monologue souverain, mais un invincible dialogue. ${ }^{21}$

Critics occasionally complain that Malraux's books on art are unnecessarily "rhetorical" and while specific instances are rarely given, this is perhaps the kind of passage they have in mind. Yet once one reads the text in the light of the argument now considered, one quickly sees that Malraux chooses his words very carefully. Great art, he reminds us, is not permanently silenced: it endures; it has a life in time. But it does not endure as a timeless presence - "en perpétuant son langage initial". The work's language - the significance of the rival world it embodies - is "sans cesse modifié" because it is in a state of continual metamorphosis as history moves on. The language is "parfois oublié" because there may be periods when, like ancient Egyptian sculpture during the long centuries of Christian belief, or Byzantine art after the Renaissance, it is no longer understood..$^{22}$ But the work is, nevertheless, "comme un écho qui répondrait aux siècles avec leurs voix successives" (even if it sometimes replies with silence) because this is a dialogue between the work's capacity to change its significance - its power of metamorphosis - and the shifting values of each passing century, not a monologue, not simply the unchanging voice of a work whose meaning and importance has been established once and for all. Crucially, also, it is an "invincible" dialogue, not because the work accedes to a timeless realm isolated from the vicissitudes of circumstance, but because it is capable of resurrection and thus of defying time, even if

\footnotetext{
${ }^{20}$ Les Voix du silence, Ecrits sur l'art (I), p. 264. The full statement is "La métamorphose n'est pas un accident, elle est la loi même de la vie de l'œuvre d'art."

${ }^{21}$ Les Voix du silence, Ecrits sur l'art (I), p. 264.

${ }^{22}$ This is not to suggest that many Byzantine works - religious mosaics and frescos, for example - did not continue to command respect as religious images.
} 
speaking a language different from that which it had originally spoken. The moment and the form of the resurrection are unpredictable because the future is unknown, but the work nevertheless achieves an unambiguous victory over time through its capacity to resuscitate and live again. Unlike the merely historical object - an old map, for example - it is not simply evidence of times gone by. It is part of our lives today, but it becomes so not because it is exempt from time but through a process in which time and change play an integral part.

It is difficult to exaggerate the importance of this argument. Elsewhere, I have described it as "an intellectual revolution" 23 and I chose those words very deliberately. Previous discussion has outlined the two explanations of the temporal nature of art that have dominated European thinking since the Renaissance - the proposition that art is eternal and the argument that art, like all other human activities, is immersed in the ongoing flow of historical change. These are the only two propositions that have made a major and lasting impact on European culture where the temporal nature of art is concerned. Certainly, different writers have presented them in different ways: Hegel's account of the link between art and history is different from that offered by Marx, and both are different again from those proposed by Hippolyte Taine and number of more recent post-Marxist thinkers. Variations such as these aside, however, these propositions are the two idées maîtresses that have governed European thinking about the temporal nature of art over the centuries since the Renaissance. Effectively, the West has said that art is either timeless or it is a creature of history. One might embroider on these ideas in various ways but there are no others.

Thus, the suggestion that there might be another alternative - that art might endure not timelessly but through a process of metamorphosis - is a matter of no small moment. Setting aside certain possible precursors in antiquity, the belief that art is eternal was born with the Renaissance. The idea that art belongs to history emerged in the nineteenth century. The proposition that art endures through metamorphosis is therefore one of only three major contributions to an understanding of the relationship between art and time that have been proposed since the Renaissance; and if we confine ourselves to explanations of how art endures, it is the only serious alternative proposed since the Renaissance, the only alternative to the traditional view that art endures timelessly. If the theory of metamorphosis is sound and the arguments advanced here have sought to show it is, both theoretically and in terms of

\footnotetext{
${ }^{23}$ Derek Allan, "An Intellectual Revolution: Malraux's Account of the Temporal Nature of Art", Journal of European Studies, 39 (2009), 198-224.
} 
compatibility with the historical record - it can justly be described as a landmark in the history of European thinking about art, a rare example of a true intellectual revolution.

Writing as far back as 1935, Malraux reminded us that 'Une œuvre d'art, c'est un objet, mais c'est aussi une rencontre avec le temps." ${ }^{24}$ Contemporary thinking about art, which pays so little attention to the relationship between art and time, seems to have forgotten this. In the terminology of the present topic, it has forgotten that as well being an object (capable of "representing", having certain visual qualities and so on), art is also able to vanquish temporal distance. Yet this is surely an astonishing state of affairs because one is, after all, speaking about one of art's fundamental and most fascinating features, recognised as such for some five hundred years of European history. Malraux has put the issue squarely back on the modern intellectual agenda. Art, he reminds us, has a unique capacity to transcend time; it is "la présence, dans la vie, de ce qui devrait appartenir à la mort". ${ }^{25}$ But it vanquishes time not, as once thought, because it is eternal, but through an endless process of metamorphosis.

\footnotetext{
${ }^{24}$ André Malraux, "Préfaces, articles, allocutions: 'L'CEuvre d'art'," in Ecrits sur l'Art (I), ed. JeanYves Tadié (Paris: Gallimard, 2004), 1188-1191, p. 1190.

${ }^{25}$ La Métamorphose des dieux: L'Intemporel, Ecrits sur l'art (II), p. 778.
} 


\section{References}

Allan, Derek. Art and the Human Adventure: André Malraux's Theory of Art. Amsterdam: Rodopi, 2009.

Allan, Derek. Art and Time. Newcastle upon Tyne: Cambridge Scholars Publishing, 2013.

Allan, Derek. “An Intellectual Revolution: Malraux's Account of the Temporal Nature of Art”, Journal of European Studies 39 (2009): 198-224.

Allan, Derek. "'Reckless Inaccuracies Abounding': André Malraux and the Birth of a Myth", The Journal of Aesthetics and Art Criticism 67, no. 2 (2009): 147-158.

Hamilton, A. "Scruton's Philosophy of Culture: Elitism, Populism, and Classic Art", British Journal of Aesthetics 4, no. 49 (2009): 389-404.

Hume, David. Of the Standard of Taste, and other essays. Edited by J.W. Lenz. Indianapolis: Bobbs-Merrill, 1965.

Malraux, André. La Métamorphose des dieux: L'Intemporel, Ecrits sur l'art (II). Edited by Henri Godard. Paris: Gallimard, 2004.

Malraux, André. La Métamorphose des dieux: Le Surnaturel, Ecrits sur l'art (II). Edited by Henri Godard. Paris: Gallimard, 2004.

Malraux, André. Les Noyers de l'Altenburg, Euvres Complètes (II). Edited by MariusFrançois Guyard, Maurice Larès and François Trécourt. Paris: Gallimard, 1996.

Malraux, André. Les Voix du silence, Ecrits sur l'art (I). Edited by Jean-Yves Tadié. 2 vols. Paris: Gallimard, 2004.

Malraux, André. 'Préfaces, articles, allocutions: 'L'Euvre d'art'.” In Ecrits sur l'Art (I), edited by Jean-Yves Tadié, 1188-1191. Paris: Gallimard, 2004.

Malraux, André. "Promenades imaginaires dans Florence". (Television series: Journal de Voyage avec André Malraux.). Paris: Interviewer: Jean-Marie Drot 1975.

Nancy, Jean-Luc. La Beauté, Les petites conférences. Montrouge: Bayard, 2009.

Perricone, Christopher. "Art and the Metamorphosis of Art into History”, British Journal of Aesthetics 31, no. 4 (1991): 310-321.

Taine, Hippolyte. Philosophie de l'Art. Vol. 1. Paris: Hachette, 1948.

Zarader, Jean-Pierre. André Malraux: Les Ecrits sur l'art. Paris: Les Editions du cerf, 2013. 
Zarader, Jean-Pierre. Malraux ou la pensée de l'art: une approche philosophique Paris: Ellipses, 1998. 